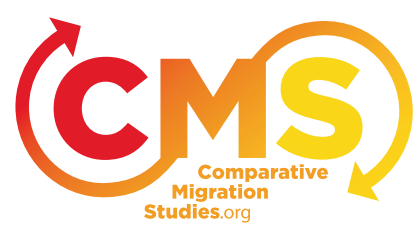

\title{
Naturalization Dynamics in Immigrant Families
}

\author{
Alex Street
}

\author{
CMS 1 (1): 23-44 \\ DOI: $10.5117 / C M S 2013.1 . S T R E$
}

\begin{abstract}
In recent decades millions of people have migrated to the democracies of North America and Western Europe. Some of these immigrants have become citizens of their new homelands, while others remain foreign residents. This article shows that the family context shapes decisions over naturalization. The costs and benefits of becoming a citizen of one's country of residence depend, in part, on the naturalization decisions of immediate family members. The article draws on evidence from interviews and census data in Austria, and extends the analysis to the USA in order to test the scope for the argument to generalize. I conclude by discussing what family-level dynamics in naturalization can teach us about the concept of citizenship.
\end{abstract}

Keywords: Citizenship, Immigration, Family

\section{Introduction}

One in eight residents of the typical OECD member state was born in another country. ${ }^{1}$ Some of these immigrants have now become citizens of their new homelands, while many others remain foreign residents. Studying why some immigrants naturalize, while others do not, promises to enhance our understanding of the conditions that promote the political incorporation of immigrants. More broadly, research on naturalization provides a fresh angle from which to consider the meaning of citizenship in contemporary democracies.

In this paper I show that studying naturalization behavior in the context of the family can help us understand why people naturalize. This focus on the family also has novel implications for our understanding of citizenship. 
The paper draws on census data and interviews from Austria, and then tests the scope for the argument to generalize by extending the quantitative analysis to the USA. These two countries have very different immigrant populations and citizenship regimes. Yet in each case the family context shapes naturalization behavior. Foreign residents who live with other people who have naturalized are more likely to have naturalized themselves. Often, multiple family members acquire citizenship in the same year. The finding that the decision to naturalize depends on the behavior of other family members suggests that attachments to particular people mediate the relationship that citizenship establishes between the individual and the state.

The next section of the article describes approaches that other scholars have taken to the study of citizenship and naturalization. I argue that the decision to naturalize has implications for one's family members, and that we should expect foreign residents to take these effects into account. I then describe the advantages of combining qualitative and quantitative evidence in research on naturalization, and introduce the Austrian and US case studies. The subsequent three sections present evidence from interviews in Austria, from Austrian census data and from census data in the USA. The penultimate section of the article compares findings from the two countries, and in the conclusion I discuss the implications of the research for our understanding of citizenship.

\section{Existing research on citizenship and naturalization}

Citizenship is at the heart of democratic politics. The attendant civil rights grant citizens the protections of the law, while political rights allow citizens to influence which laws are adopted. ${ }^{2}$ Most residents of contemporary democracies were born into their current citizenship, having inherited citizenship from their parents or acquired it by place of birth (Waldrauch, 2006). Viewed as a birthright, citizenship is easily taken for granted (Shachar, 2009). Indeed, the presumption that residents should have citizenship is apparent in the very word 'naturalization' (Smith, 1997). But citizenship is too important to be taken for granted. Studying the behavior of immigrants, who face a choice over citizenship, can help scholars answer important questions. Which aspects of citizenship do immigrants value highly enough that they are persuaded to naturalize? Which features of the social and political context help to convince foreign residents that they can and should become citizens of their country of residence? In this article I offer some 
novel answers to these questions, by studying family-level dynamics in naturalization, where each person's decision to naturalize depends, in part, on the decisions of others in the family.

Existing research on naturalization has tended to focus either on citizenship laws (e.g. Howard, 2009; Janoski, 2010) or on individual decision-making (e.g. DeVoretz, 2008; Kahanec \& Tosun, 2009). Citizenship laws determine who gets citizenship at birth, and also establish the criteria that people wishing to naturalize must meet. Immigrants who aim to naturalize must typically provide evidence of a minimum period of residence and of economic self-sufficiency, and must show proof of integration, for example by passing a language or civics test (Goodman, 2012). Immigrants must also decide whether the benefits of naturalization-including irrevocable residence rights, access to all sectors of the labor market, and political rights - are worth the costs and administrative trouble. Scholars have shown that naturalization rates are higher among refugees, who are unlikely to return to the country of origin. Naturalization is also more likely among immigrants who have lived in the country for many years, those who are more educated, and those who are more interested in political participation (Bloemraad, 2006; Ramakrishnan \& Espenshade, 2001; Portes \& Curtis, 1987; Vink, Prokic-Breuer \& Dronkers, 2012). Some research suggests that the prospect of losing one's citizenship of birth discourages naturalization, though others dispute this claim (Anil, 2007; Jones-Correa, 2001; Mazzolari, 2009; Scott, 2008).

Scholars have paid relatively little attention to social dynamics that operate between the micro-level of the individual and the macro-level of the polity. However, there are strong reasons to expect that social dynamics shape naturalization behavior. First, the costs of naturalization may be lower, when others are also naturalizing. This could be true, for example, if information about the naturalization procedure spreads within immigrant communities, or if immigrants are able to help each other apply. Second, the benefits of naturalization may be greater, when other foreign residents are also naturalizing. For instance, the influence of immigrant-origin residents as a voting bloc will increase, as more people naturalize. Immigrants may be more inclined to naturalize in order to facilitate travel, if their friends or family members are also naturalizing, since it is often preferable to travel along with one's family or friends.

Interpersonal dynamics in the decision to naturalize should be especially pronounced within the family. People who naturalize are often eligible to 'extend' citizenship to their immediate family, meaning that spouses and minor children can naturalize for reduced fees or without having to meet 
the standard requirements. As a result, parents who expect their children to benefit from acquiring citizenship while young may naturalize for the sake of their children. The sense of legal security that comes with citizenship may be all the more valuable, if one's family members are also able to naturalize. Hence family members may prefer to naturalize together. People with higher incomes can help to pay the fees for family members applying to naturalize, and those who are better at dealing with bureaucratic requirements may take charge of the paperwork for the whole family. Finally, immigrants may even be motivated to naturalize in order to sponsor family members living abroad to join them in the country. In short, the decision to become a citizen of one's country of residence has implications for one's family, and we should expect these effects to be taken into account by people facing a decision over naturalization.

Legal scholars have recognized that citizenship laws rely heavily on attribution within the family, and that many countries facilitate naturalization through marriage. Indeed, Knop (2001) argues that scholars should pay greater attention to the ways in which the legal recognition and regulation of family relationships have impinged on citizenship laws. Knop argues that more research is needed on 'relational nationality.' As yet, however, few empirical studies of naturalization have heeded this call.

Scholars have used both qualitative and quantitative research methods to study naturalization behavior. Qualitative studies, often based on interviews, more often emphasize social dynamics. For example, Bloemraad (2006) uses interview data to show how immigrants draw on resources from immigrant communities, and from the state, in order to meet the costs of naturalization. ${ }^{3}$ Alvarez (1987) identifies ties to family members in the country of residence as a factor leading to naturalization, though Anil (2007) notes that family ties may encourage immigrants to remain in the country but do not always suffice to prompt naturalization. Topçu (2007) provides evidence of family members helping each other naturalize, but also of disagreement within families over the value of becoming a citizen of the country of residence. De Hart (2010) shows that parents, especially mothers in inter-national marriages, care deeply about the citizenship status of their children. Levesley (2008, p. 30) notes that having children can serve as a 'catalyst' that prompts foreign residents to naturalize. Revealing as these studies are, none of them provides broad evidence on the numbers of people who are prompted to naturalize, or are dissuaded, depending on the implications of the decision for their family members.

Several quantitative studies emphasize social dynamics in explaining why foreign residents naturalize, though the available data often make 
it difficult to provide direct evidence on the posited mechanisms. For example, owning property in the country of residence is seen as evidence of having put down roots in the host society (e.g. Portes \& Curtis, 1987), but could simply indicate wealth. Using data from the 1970s, Yang (1994) reports higher naturalization rates in the USA among immigrant groups that are larger in number and more concentrated in urban areas, but provides no direct evidence for his claims that this is because larger migrant groups are more likely to assimilate, or that urban concentration speeds the flow of information about naturalization. Liang (1994, p. 431) notes that immigrants who live in the same household as others who have naturalized are more likely to have naturalized themselves, but provides no evidence to support his claim that this is because family members share 'social capital,' which 'reduces the anxiety and cost of naturalization and facilitates the actual process.' One way to provide stronger evidence on social dynamics in naturalization behavior is to combine quantitative and qualitative methods, in order to supplement data on variation in citizenship status with evidence on the mechanisms behind the observed patterns.

\section{Cases, data and methods}

In order to advance our understanding of social dynamics in naturalization behavior, and especially the role of the family, this paper presents evidence from both interviews and census data. Interviews with immigrant-origin residents of Austria provide insights on the reasons why people naturalize. Analysis of Austrian census data allows me to test the prevalence of these motives, by comparing the characteristics of immigrants who have naturalized with those of people who have not. I take advantage of the fact that the census data contain information not just on individuals but on entire households, allowing me to study naturalization behavior in the family context. Finally, I also subject the arguments developed in this paper to further testing, by comparing the findings from the Austrian case with evidence from census data in the USA.

The recent history of immigration to Austria has close parallels to that of other Central and West European countries. The country is home to around 1.2 million people who were born abroad, and a further 250,000 who were born in Austria to immigrant parents (many of whom inherited foreign citizenship, since the country does not automatically grant Austrian citizenship to people born in the country). Together, immigrants and their children account for around $17 \%$ of the total population. Like Germany, 
Austria recruited 'guest workers' from the former Yugoslavia and Turkey to help fuel the booming economy of the 196os. Although many of the 'guests' returned to their countries of origin, some stayed and later brought family members to join them (Gürses, Mattl-Wurm, \& Kogoj, 2004). Austria is also similar to countries such as France, Spain and the UK, in that it is home to relatively many immigrants from the former empire, especially the former Yugoslavia. Austrian citizenship law is typically seen as restrictive, because of the lack of a provision for citizenship by birth in the country, and because immigrants who wish to naturalize are required to have lived in the country for many years, to pass strict integration tests and to pay high fees (Çınar, 2010; Perchinig, 2010). However, Austrian citizenship law does make it relatively easy for the family members of people who naturalize to acquire citizenship. Minor children of people who naturalize are automatically eligible for citizenship, and it is also relatively easy to 'extend' citizenship to one's spouse (Çınar, 2010; Mussger, Fessler \& Szymanski, 2001).

I conducted a total of 36 interviews in Austria. 21 of the interview subjects were immigrant-origin residents, twelve of whom (57\%) held Austrian citizenship. Of the remaining interviewees, three were politicians who spoke for their parties on citizenship law, six were civil servants who administered citizenship law, and seven worked for NGOs that provide advice on naturalization. Interview subjects were recruited using snowball sampling: initial contacts at migrant organizations in three regions were asked to suggest other people who would be willing to talk. ${ }^{4}$ Snowball sampling is an efficient way to recruit uncommon and possibly reluctant interview subjects, but is liable to result in a non-representative sample. Because it is difficult to assess the uncertainty involved in drawing inferences from the non-representative sample, in this paper I use interview data only to illustrate the mechanisms at work. Hence I do not report the frequency with which particular motives were reported.

I supplement the interview data with evidence from the Austrian micro-census, a large quarterly household survey. Participation is obligatory, and the sample is representative of the resident population (Stadler \& Wiedenhofer-Galik, 2008). I use data from the spring of 2008 , when a special module was included with questions for immigrants and the children of immigrants. This allows me to identify both foreign residents and naturalized Austrians. Although many scholars have used census data to study individual-level variation in citizenship status, few have exploited the household-level structure of these data to study patterns within the family. ${ }^{5}$ In order to make use of this information, I constructed indicators showing the proportion of household members who have naturalized, and 
also whether each person naturalized at the same time as any others in the household. Evidence on simultaneous naturalizations provides stronger support for the claim that decisions to naturalize are interdependent within the family. One would expect to observe some clustering of citizenship status, at the household level, simply because family members share various characteristics. The fact that family members often naturalize in the same year implies that there are social dynamics at work that go beyond mere similarity within households.

Finally, I conduct an initial test of whether mechanisms similar to those at work in Austria also apply in the USA. The USA also has a large foreign-born population, around $13 \%$ of the total population. US citizenship law is liberal, with automatic citizenship for anyone born in the country and relatively easy naturalization. As in Austria, the minor children of parents who naturalize also 'derive' a right to citizenship. The advantage of comparing Austria with a country with very different citizenship laws is that this provides a hard test of the claim that the family context shapes naturalization behavior under a broad range of conditions. The family context should not be expected to have identical implications across cases, however. For example, citizenship of the USA is granted to anyone born in the country, under the principle of jus soli. This helps to ensure that relatively few children grow up in the country as foreigners. In contrast, in countries like Austria that do not apply jus soli, many immigrant parents have an incentive to naturalize in order to ensure that their children grow up with citizenship of the country of residence. One would expect parents in both countries to take account of the implications of the decision to naturalize for their children, but this may play out in different ways. In order to provide an initial test of this argument I analyze census data from the USA, namely from the 2009 American Communities Survey (ACS). Again, these data provide information on entire households, and I created indicators for each household to record simultaneous naturalizations.

\section{Findings from interviews in Austria}

When asked about the decision over naturalization, many interview subjects in Austria reported that other family members had been involved. The account of a Turkish-origin woman, who works in a public relations company in Vienna, provides an example of social dynamics in naturalization. ${ }^{6}$ She said that her mother had naturalized in the early 1990s, along with her three children. The family took advantage of a provision allowing parents who 
naturalize to 'extend' citizenship to their children. The parents wanted their children growing up in the country to hold Austrian citizenship. The interview subject said she was glad to have naturalized together with her mother and siblings, since it would have been more difficult to do so on her own. This woman's father chose to retain his Turkish citizenship, however, since he was worried that he would not otherwise be eligible for an Islamic burial in Turkey. The interview subject said that her father sometimes appears to regret his decision. He is interested in Austrian politics, but frustrated to have no right to vote: 'And without a vote... somehow you don't really exist.' This statement illustrates what is at stake in the decision over naturalization.

Another interview subject, originally from Iran, recounted how she had benefited from the provision allowing citizenship to be 'extended' to spouses. ${ }^{7}$ She was eager to naturalize but, without a job at the time, was not eligible. However, a helpful civil servant pointed out that it would be possible for her to become an Austrian citizen by extension if her husband naturalized. He did so, and the woman explained that it was a 'relief' for the two of them to have the security of citizenship, before she had her first child. Help from family members is not always sufficient to allow people to naturalize, however. One student described the efforts of her parents to help her meet the requirements, which became more demanding after a reform of citizenship law in 2006. ${ }^{8}$ Her parents began transferring a regular sum to her bank account so that she could show that she met the minimum income requirement, but civil servants were not convinced that the transfers would continue. The student portrayed the pursuit of citizenship, with the help of her parents, as a collective endeavor, and spoke on behalf of her family in saying that they were 'extremely frustrated' by the difficulty of the procedure. An employee of an NGO that provides immigrants with advice on citizenship explained to me that the high fees and minimum income standards mean that it is now 'all but impossible' for low-income immigrants to naturalize. ${ }^{9}$

A senior official in the administration of Austrian citizenship law told me that 'In Austria we make citizenship easier for family members because we have a traditional view. We see the family, not the individual, as the basic unit of society. ${ }^{10} \mathrm{He}$ said that this principle has become less important since a reform of citizenship law in the year 2006, which requires that each applicant for citizenship meet new integration requirements. Nonetheless, immigrant interview subjects reported that civil servants appear more receptive to applications for naturalization that include all family members. One immigrant from Morocco, who naturalized with 
her spouse and daughters, explained that the bureaucratic preference for unitary citizenship in the family matched her own belief that 'things are just easier' when family members all hold the same citizenship. ${ }^{11}$

Not all of the people interviewed wanted to become Austrian citizens. One explained that she sees few benefits in doing so, since naturalization is expensive and she has many rights as a permanent resident. ${ }^{12}$ Her mother also lives in Austria as a foreign resident, and the interview subject sees their citizenship (of Bosnia-Herzegovina) as a tie between the two of them. Another foreign resident who does not wish to naturalize, because he still feels attached to his country of birth, Serbia, said that he was nonetheless glad that his children had grown up with Austrian citizenship, inherited from his Austrian wife. ${ }^{13}$ It should also be noted that family ties were not the only factors that interview subjects discussed as reasons for or against naturalization. Other considerations included a desire for fully secure residence rights, and the fact that many immigrants can travel more easily with an Austrian passport.

In sum, the interviews conducted in Austria provide examples of many ways in which family members can influence each others' decision to naturalize. Family members can help each other pay the required fees or overcome administrative difficulties. Some people feel more comfortable as citizens of a new country, if other family members also become citizens. The legal security of citizenship is valued all the more when it is shared with members of one's immediate family. Some parents naturalize for the sake of their children, and some spouses naturalize for the sake of their partners. I now turn to census data to provide evidence on the prevalence of these patterns.

\section{Findings from Austrian census data}

Table one provides an overview of the people living in Austria as foreign residents or naturalized citizens (whom I describe, for the sake of brevity, as the immigrant-origin population). The table reveals that the immigrantorigin population is well established in Austria, with the average member of this group having lived in the country for over 20 years. Roughly one in five immigrant-origin residents was born in Austria. Most were born, or have parents who were born, in Western or Eastern Europe, or in the Balkans. We also see that around two in five now hold Austrian citizenship. 
Table 1 Immigrant-origin population of Austria, as of 2008. Source: Austrian MicroCensus, Quarter 2, 2008. Estimates to the nearest thousand; all calculations by the author. 'Immigrant-origin' refers to foreign residents and people who have naturalized

\begin{tabular}{lcccc}
\hline $\begin{array}{l}\text { Country/region } \\
\text { of origin }\end{array}$ & $\begin{array}{c}\text { Number of } \\
\text { residents }\end{array}$ & $\begin{array}{c}\text { \% born in } \\
\text { Austria }\end{array}$ & $\begin{array}{c}\text { Mean years } \\
\text { of residence }\end{array}$ & $\begin{array}{c}\text { \% with } \\
\text { Austrian } \\
\text { citizenship }\end{array}$ \\
\hline E. Europe & 237,000 & $9 \%$ & 25 & $47 \%$ \\
W. Europe & 243,000 & $11 \%$ & 23 & $22 \%$ \\
Turkey & 212,000 & $25 \%$ & 17 & $49 \%$ \\
Former Yugoslavia & 451,000 & $23 \%$ & 20 & $34 \%$ \\
Other & 225,000 & $25 \%$ & 18 & $47 \%$ \\
TOTAL & $1,368,000$ & $19 \%$ & 21 & $39 \%$
\end{tabular}

The census data can be analyzed for information on the distribution of immigrant-origin residents across households. The data reveal that $10 \%$ live in single-person households, and an additional $18 \%$ live as the only foreign resident or naturalized citizen in a household otherwise made up of nativeborn Austrian citizens. Among those who live with other immigrant-origin residents, citizenship status is clustered by household. Just $13 \%$ of those who live with other immigrants, none of whom have naturalized, now hold Austrian citizenship themselves. Conversely, $61 \%$ of those who live with at least one other person who has naturalized are also now Austrian citizens. Figure one shows naturalization patterns across households with varying numbers of immigrant-origin residents. In the top-left panel of the figure, we see that $28 \%$ of those who live with one other immigrant-origin resident, who hasn't naturalized, are now Austrian citizens themselves, whereas $60 \%$ of those who live with someone who has naturalized are also Austrian citizens. In the other panels we see that living with others who have naturalized becomes an increasingly strong predictor of citizenship status, in households with more immigrant-origin residents. In households with four immigrant-origin residents, for example, the share with Austrian citizenship is just $2 \%$ when no others have naturalized, compared to $97 \%$ when all three of the other people have become Austrian citizens. 

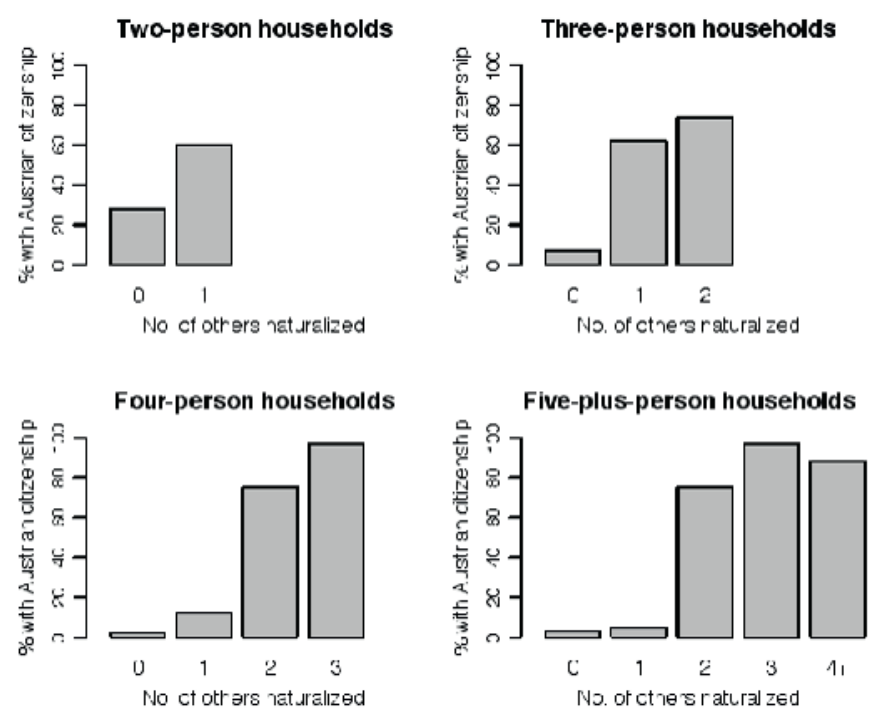

Figure 1 Immigrant-origin residents of Austria, who live with others who have naturalized, are more likely to have naturalized themselves

Source: Austrian Micro-Census, Quarter 2, 2008. All calculations by the author. The number of persons in the household refers to people for whom the question overnaturalization applies, i.e. foreign residents or naturalized citizens.

It is important to establish whether this association between each person's citizenship status, and that of others in the household, is also robust in multivariate models that control for other factors related to naturalization. Table two presents the results of two statistical models, which predict the citizenship status of immigrant-origin residents based on their characteristics and the contexts in which they live. Both models include variables that existing research has shown to be associated with naturalization, including gender and marital status, age and length of residence, country of birth, educational attainment and property ownership. I also include indicators to account for variation across the Austrian states. The first model achieves quite good fit, correctly predicting an additional $50 \%$ of cases, compared to the baseline of predicting that every person in the data falls into the modal outcome category (in this case, that means predicting that nobody has naturalized). The second model is identical to the first, but also includes a variable indicating whether the person in question lives with anyone else who has naturalized. We see that the coefficient is positive and highly significant, and that including this one additional variable leads to a substantial improvement in the fit of the model, which now correctly 
predicts an additional $60 \%$ of cases, compared to the baseline. Based on the estimates from model two, the predicted likelihood of holding Austrian citizenship is 0.38 for a typical immigrant-origin resident who lives with no others who have naturalized, compared to 0.82 for an otherwise similar person who lives with at least one other naturalized Austrian citizen. ${ }^{14}$

Table 2 Logistic models of Austrian citizenship status. Note: the table reports point estimates and standard errors (in parentheses) from logistic regressions fit by iteratively re-weighted least squares. Standard errors are clustered by household. ** indicates significance at $p<0.01,{ }^{*}$ indicates $p<0.05$. Model 2 is the same as Model 1 except that it also includes a dummy variable for those who live with others who have naturalized. The education reference category is no certificate or only primary schooling, and includes those still in school. Dichotomous variables are indicated with (0/1). The data source is the Austrian micro-census data from the second quarter of 2008 , with the analysis restricted to households that provided information for all household members

\begin{tabular}{|c|c|c|}
\hline & Model 1 & Model 2 \\
\hline \multirow[t]{2}{*}{ Female (0/1) } & $0.33^{* *}$ & $0.30^{*}$ \\
\hline & $(0.10)$ & $(0.12)$ \\
\hline \multirow[t]{2}{*}{ Married (0/1) } & 0.02 & -0.27 \\
\hline & $(0.13)$ & $(0.14)$ \\
\hline \multirow[t]{2}{*}{ Log age } & $-0.99 * *$ & $-1.03^{* *}$ \\
\hline & $(0.23)$ & $(0.24)$ \\
\hline \multirow[t]{2}{*}{ Log years in country } & $2.60^{* *}$ & $2.83^{* *}$ \\
\hline & $(0.18)$ & $(0.20)$ \\
\hline \multirow[t]{2}{*}{ Born Austria (0/1) } & 1.00 & 1.14 \\
\hline & $(0.69)$ & $(0.71)$ \\
\hline \multirow[t]{2}{*}{ Log years in country*Born in Austria } & $-0.55^{* *}$ & $-0.62^{* *}$ \\
\hline & $(0.20)$ & $(0.21)$ \\
\hline \multirow[t]{2}{*}{ Secondary education $(0 / 1)$} & $0.45^{* *}$ & $0.53^{* *}$ \\
\hline & $(0.15)$ & $(0.15)$ \\
\hline \multirow[t]{2}{*}{ University (0/1) } & $0.42^{*}$ & $0.48^{*}$ \\
\hline & $(0.18)$ & $(0.19)$ \\
\hline \multirow[t]{2}{*}{ Owner-occupied housing $(0 / 1)$} & $0.66^{* *}$ & $0.58^{* *}$ \\
\hline & $(0.17)$ & $(0.15)$ \\
\hline \multirow[t]{2}{*}{ Live with other(s) who have naturalized $(0 / 1)$} & - & $2.03^{* *}$ \\
\hline & & $(0.23)$ \\
\hline Region of origin fixed effects & yes & yes \\
\hline State fixed effects & yes & yes \\
\hline \multirow[t]{2}{*}{ Constant } & $-4.95^{* *}$ & $-6.06^{* *}$ \\
\hline & $(0.66)$ & $(0.69)$ \\
\hline No. of individuals & 2520 & 2520 \\
\hline Log-likelihood & -1086 & -983 \\
\hline Percentage Reduction in Error & $50 \%$ & $60 \%$ \\
\hline
\end{tabular}


Finally, I make use of information on the timing of naturalization to support the claim that the clustering of citizenship status by household reflects interpersonal dynamics, rather than merely the similarity of people who live together. As was noted above, $61 \%$ of those who live with one or more others who have naturalized are Austrian citizens themselves. In two thirds of these cases, the people involved naturalized in the same year. This suggests that these family members reached a collective decision over naturalization. Following my argument, one would also expect simultaneous naturalizations to be concentrated in family-based households, as opposed to households made up of unrelated individuals. Indeed, this is what we find: just $2 \%$ of those who have naturalized, and live in non-family-based households, became citizens at the same time as one of their housemates. Consistent with the interview data showing that children are often included in the citizenship applications of their parents, we also find that simultaneous naturalizations are common among those living with their parents. $75 \%$ of immigrant-origin children living with someone who has naturalized have become Austrian citizens themselves, and in five out of six cases they acquired citizenship in the same year.

To summarize the results thus far, the evidence from interviews in Austria revealed some of the ways in which family members can stimulate each other to naturalize, or help each other through the process of acquiring citizenship. The Austrian census data showed that this kind of social dynamic is quite common in naturalization behavior. People are more likely to have naturalized, if they live with others who have taken this step. Often, multiple family members acquire citizenship of their country of residence in the same year.

\section{Findings from US census data}

In this section of the paper I present evidence of household-level naturalization dynamics in the USA. I begin by providing an overview of the foreign-born population, i.e. the group of people for whom the question of naturalization arises. ${ }^{15}$ Table three provides descriptive statistics. 
Table 3 Foreign-born population of the US, as of 2009. Source: American Communities Survey 2009. Estimates to the nearest thousand; all calculations by the author. Note that Asia is defined to include Australasia

\begin{tabular}{lccc}
\hline $\begin{array}{l}\text { Country/region } \\
\text { of origin }\end{array}$ & $\begin{array}{c}\text { Number of } \\
\text { residents }\end{array}$ & $\begin{array}{c}\text { Mean years of } \\
\text { residence }\end{array}$ & $\begin{array}{c}\text { \% with US } \\
\text { citizenship }\end{array}$ \\
\hline Africa & $1,505,000$ & 13 & $43 \%$ \\
$\begin{array}{l}\text { Americas (excluding } \\
\text { Mexico) }\end{array}$ & $9,931,000$ & 21 & $43 \%$ \\
Asia & $10,732,000$ & 18 & $57 \%$ \\
Europe & $5,163,000$ & 27 & $59 \%$ \\
Mexico & $11,580,000$ & 17 & $22 \%$ \\
TOTAL & $38,911,000$ & 19 & $43 \%$ \\
\end{tabular}

We see in table three that the mean length of residence, for the foreign-born population of the USA, is almost 20 years. Around two in five are now US citizens. The share with citizenship is lower for Mexican immigrants, at least in part because many are undocumented. It is estimated that around six and a half million Mexicans live in the USA without authorization (Taylor, Lopez, Passel \& Motel, 2011). Note that, because of the jus soli provision in the US, there is no need for a column showing the proportion of foreign residents who were born in the country.

As in the Austrian case, I make use of the household-level structure of the census data to describe family dynamics in naturalization behavior. The data reveal that $9 \%$ of the US foreign-born live in single-person households, and an additional $16 \%$ are the only immigrants in households that also contain US citizens. Focusing on those who live with other immigrants, we see that citizenship status is clustered by household. Just $13 \%$ of those who live with other immigrants, but with no naturalized citizens, are US citizens themselves. In contrast, $69 \%$ of those who live with one or more naturalized citizens have naturalized themselves. Figure two presents information on the clustering of citizenship status, broken down by the number of immigrants in the household. The top-left panel shows that, in households with two immigrants, the share with US citizenship is $78 \%$ if the other person has naturalized, compared to $21 \%$ if he or she has not done so. The other panels show that an immigrant is increasingly likely to have become a citizen, as the number of other naturalized citizens in the household rises. 


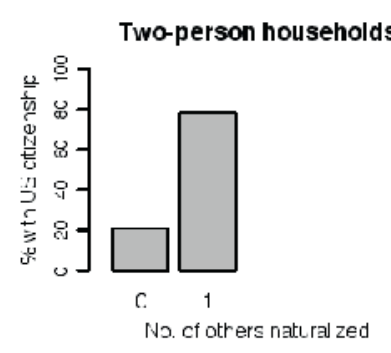

Four-person households

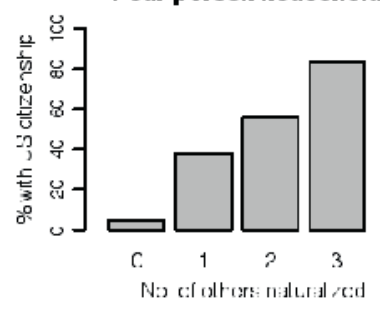

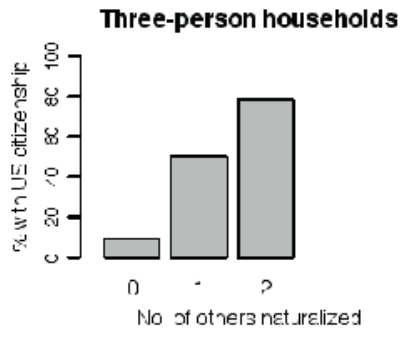

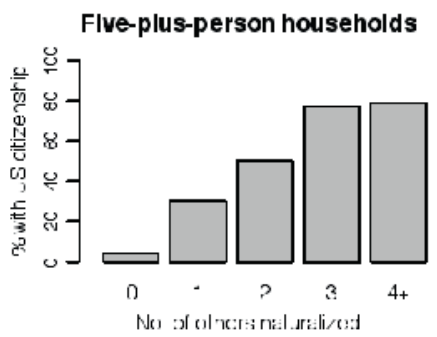

Figure 2 Immigrants in the US, who live with others who have naturalized, are more likely to have naturalized themselves

Source: American Communities Survey 20o9. All calculations by the author. The number of persons in the household refers to people for whom the question over naturalization applies, i.e. foreign residents or naturalized citizens.

In order to test whether the household-level clustering of citizenship status is due to other factors that make people more or less likely to naturalize, table four reports the results of logistic models of citizenship status. The models include variables that existing research has shown to be associated with naturalization, such as gender and marital status, age and length of residence, country or region of birth, educational attainment and property ownership in the USA. I also control for variation across US states. Model three achieves good fit, correctly predicting an extra $57 \%$ of cases, compared to the baseline prediction that everybody falls into the modal outcome category. Model four is similar to model three, but also includes a variable indicating whether the person lives with anyone else who has naturalized. The coefficient is positive and highly significant. Including this variable improves the fit of the model, up to $61 \%$ reduction in error. Based on the coefficients from model four, the predicted likelihood of holding US citizenship is 0.41 for a typical immigrant-origin resident who lives with no others who have naturalized, compared to 0.76 for someone who lives with at least one naturalized US citizen. ${ }^{16}$ 
Table 4 Logistic models of holding US citizenship. Note: the table reports point estimates and standard errors (in parentheses) from logistic regressions fit by iteratively reweighted least squares. Standard errors are clustered by household. ${ }^{* *}$ indicates significance at $p<0.01,{ }^{*}$ indicates $p<0.05$. Model 2 is the same as Model 1 except that it also includes a dummy variable for those who live with others who have naturalized. The education reference category includes those with no qualifications and people too young to have finished school. Dichotomous variables are indicated with (0/1). The data source is the American Communities Survey, 2009

\begin{tabular}{lcc}
\hline & Model 3 & Model 4 \\
\hline Female (0/1) & $0.21^{* *}$ & $0.23^{* *}$ \\
Married (0/1) & $(0.01)$ & $(0.01)$ \\
& $0.12^{* *}$ & -0.01 \\
Log age & $(0.01)$ & $(0.01)$ \\
& $-0.12^{* *}$ & $-0.22^{* *}$ \\
Log years in country & $(0.02)$ & $(0.02)$ \\
& $1.79^{* *}$ & $1.87^{* *}$ \\
Secondary education (0/1) & $(0.01)$ & $(0.01)$ \\
& $-0.73^{* *}$ & $0.67^{* *}$ \\
University (0/1) & $(0.02)$ & $(0.02)$ \\
& $-0.16^{* *}$ & 0.03 \\
Owner-occupied housing (0/1) & $(0.02)$ & $(0.02)$ \\
& $0.64^{* *}$ & $0.33^{* *}$ \\
Live with other(s) who have naturalized (0/1) & $(0.01)$ & $(0.01)$ \\
& - & $1.53^{* *}$ \\
Region of origin fixed effects & & $(0.02)$ \\
State fixed effects & yes & yes \\
Constant & yes & yes \\
& $-4.40^{* *}$ & $-4.50^{* *}$ \\
No. of individuals & $(0.15)$ & $(0.14)$ \\
Log-likelihood & 333,230 & 333,230 \\
Percentage Reduction in Error & -17320726 & $61 \%$ \\
\end{tabular}

Finally, I again turn to information on the timing of naturalization. As was reported above, $69 \%$ of immigrants who live with one or more other people who have naturalized have become US citizens themselves. In two fifths of these cases, the people in question became US citizens in the same year. This is much higher than would be observed due to chance alone, if the timing of naturalization among people living together were independent. However, this share is lower than the equivalent figure in Austria (two thirds). In other words, in the USA it is relatively common for multiple household members to have naturalized, but for some to have taken this step earlier than others. The US census data also show that simultaneous naturalizations are observed almost exclusively in family-based households: 
only $4 \%$ of those who have naturalized, and live in non-family-based households, became citizens at the same time as one of their housemates. We also see that simultaneous naturalizations are relatively common among children. $71 \%$ of immigrant children living in a household where others have naturalized, have also become US citizens. And in three out of five of these cases, they became US citizens in the same year as at least one other household member.

\section{Discussion}

This paper provides evidence that many immigrants obtain citizenship of their country of residence because other family members naturalize and include them in the process. Others receive help and encouragement from their family. The combination of interviews and census data, from the Austrian case, provided the clearest evidence of family-level dynamics, and the analysis of census data from the USA suggested that similar forces are at work even in a country with a very different immigrant population and citizenship laws.

Comparing the findings from the two cases suggests a number of areas for further research. The association between naturalization, and living with others who naturalize, is stronger in Austria than in the USA. This is clear from comparing figures one and two, and tables two and four. Comparing the two figures we see broad parallels, but also some differences. First, the association levels off at a lower rate, in the USA. In households where several people have naturalized, in Austria, the remaining person is almost certain to have naturalized. Whereas in the USA, even if all of the others in the household have naturalized, the percentage with US citizenship peaks at around $80 \%$. A second difference is that, in larger households in Austria, the clustering of citizenship status rises sharply, once two others have naturalized. In the USA, the rise is more gradual. These differences can be explained, at least in part, by the fact that many of the larger households in Austria contain children born in the country without Austrian citizenship. These children are often included when their parents naturalize. In the USA, however, birthright citizenship limits the number of children growing up without US citizenship. Hence in the USA, the households with many immigrants often include more distant relatives such as aunts, uncles or grandparents, who are less likely to naturalize at the same time as each other. 
The variable indicating the presence of one or more other naturalized citizens also allows for a larger improvement in the fit of multivariate statistical models in Austria than in the USA, as can be seen from comparing tables two and four. Again, this reflects the different composition of multi-immigrant households in the two countries. Additionally, in the US, those who live with other naturalized citizens are more similar in other ways. For example, the length of residence is more similar across household members. For this reason, including the variable indicating that others have naturalized brings less additional predictive power.

These findings reveal the importance of household composition for naturalization behavior. The decision over whether to naturalize plays out in a different context, for people who live with native citizens, for parents who live with their immigrant-origin children, and for those who live with extended immigrant-origin family members. Some of this contextual variation is due to citizenship laws, especially relating to citizenship by birth in the country. More broadly, however, household composition can vary as the result of processes of adaptation and selection on the part of both immigrants and the receiving society—consider, for example, the case of inter-national marriages. To better understand variation in the distribution of foreign residents across households, and the implications for citizenship, it may be fruitful to link research on naturalization with research on racial and ethnic intermarriage (e.g. Alba and Nee, 2003; Qian and Lichter, 2007). Finally, while this paper's efforts to draw extra information from the household-level structure of census data have revealed new patterns, it should be noted that scholars wishing to study family members who do not live together, or couples unable to marry, will have to draw upon other sources, such as self-reports in surveys of immigrants.

\section{Conclusion}

Studying naturalization dynamics in immigrant families has shown that personal ties often influence the decision over whether to become a citizen of one's country of residence. This finding enhances our understanding of immigrant incorporation. Furthermore, the evidence presented here casts new light on the concept of citizenship. Scholars define citizenship as a status of political membership, but many also argue that citizenship involves a feeling of belonging (e.g. Bosniak, 2000; Carens, 2000; Cohen, 1989). It is widely thought that this affective dimension of citizenship is motivated by nationalism, and indeed there is evidence that conceptions of 
national identity are linked to popular attitudes on the meaning of citizenship (Citrin, Reingold and Green, 1990; Sniderman, Hagendoorn and Prior, 2004; but see also Bail, 2008). However, loyalty to the nation may not be the only basis for the feeling that one belongs as a citizen. Relations with family members can buttress and may even help to define the more abstract relationship to one's country of citizenship.

Immigrants are in a unique position to help us understand the links between citizenship and feelings of belonging. This is in part because immigrants are among the few people who actually face a decision over becoming a citizen of the country of residence. In addition, the citizenship status of immigrants intersects in a range of ways with other factors that create ties to the country, including relationships with family members who live there. Other scholars have studied immigrants in inter-national marriages. For example, Knop (2001: 111) argues that for a person married to the citizen of another country, family relations 'help to constitute her loyalties to her own state and theirs.' Scholars of transnationalism have shown that transnational ties can influence integration patterns across generations (Jones-Correa, 1998; Levitt, 2001; Vertovec, 2004; Levitt and Jaworsky, 2007). Here, I have provided evidence on the ways in which family ties in households with varying combinations of immigrants and nativeborn citizens can influence the decision to become a citizen and, as such, a full member of the polity. Future research could build on these findings to study exactly how family ties work to hold political communities together, or indeed how family ties create loyalties that cut across state borders.

\section{Acknowledgements}

Support for this research was provided by the Institute for European Studies at UC Berkeley and the Austrian Marshal Fund. I thank Rainer Bauböck, Irene Bloemraad, Jack Citrin, Taeku Lee, Jonah Levy, Ines Michalowski, Bernhard Perchinig and Wiebke Sievers for support and suggestions, and the CMS editors and two anonymous reviewers for useful comments.

\section{Notes}

1. The number of foreign-born residents in the twenty-eight OECD member states for which data are available is 108.6 million, in a population of 851.7 million. The median share of foreign residents is $13 \%$. See OECD 2013: $360-361$. 
2. As Rousseau (1997, p. 54 ) put it, 'obedience to the law one has prescribed for oneself is freedom.'

3. Bloemraad also reports statistical evidence that similar immigrants are more likely to naturalize in Canada than in the US.

4. All interviews were conducted in German by the author. Interviews were conducted in three Austrian regions: 1 ) Vienna, home to $39 \%$ of the country's foreign resident population and $41 \%$ of naturalized citizens, 2) Styria, a largely rural state that is home to $9 \%$ of the country's foreign residents and $8 \%$ of the naturalized, and 3 ) Carinthia, another mainly rural state that is a stronghold of the far-right Freedom Party, and home to $4 \%$ of the country's foreign residents and $3 \%$ of the naturalized citizens.

5. Only Liang (1994) makes explicit use of information on other household members.

6. Author interview with Linda S., Vienna, 3o June 2010.

7. Author interview with Salomeh A., Graz, 2 July 2010.

8. Author interview with Elivra K., Vienna, 22 July 2010.

9. Author interview with Gabriele F., Vienna, 14 July 2010. Federal fees for naturalization are now $€_{700}$ per person, and states charge additional fees ranging from $€_{217}$ to $€_{7} 6$ o per person. In addition, applicants must provide evidence that their earnings have been above the minimum wage for the entirety of the past three years.

10. Author interview with Josef F., Graz, 2 July 2010.

11. Author interview with Fatima K., Villach, 7 July 2010.

12. Author interview with Ivana M., Vienna, 30 June 2010.

13. Author interview with Borko I., Vienna, 6 July 2010.

14. To generate predicted probabilities, I define a typical member of the immigrant-origin population as a 33-year-old married woman, born in the former Yugoslavia, who has lived in Austria (in Vienna) for 21 years and has a secondary education.

15. Note that the institution of birthright citizenship means that in the US, only immigrants face the question of naturalization. This contrasts with the situation in Austria, where the foreign resident population includes some people born in the country.

16. To generate predicted probabilities, I define a typical member of the immigrant-origin population as a 39-year-old married woman, from Asia, who has lived in the US for 19 years and has a secondary education.

\section{References}

Alba, R., \& Nee, V. (2003). Remaking the American Mainstream: Assimilation and Contemporary Immigration. Cambridge, MA: Cambridge University Press.

Alvarez, R. R. (1987). A Profile of the Citizenship Process among Hispanics in the United States. International Migration Review, 21, 327-351.

Anil, M. (2007). Explaining the Naturalisation Practices of Turks in Germany in the Wake of the Citizenship Reform of 1999. Journal of Ethnic and Migration Studies, 33, 1363-1376.

Bloemraad, I. (2006). Becoming a Citizen: Incorporating Immigrants and Refugees in the United States and Canada. Berkeley, CA.: University of California Press.

Bosniak, L. (2000). Citizenship Denationalized. Indiana Journal of GlobalLegal Studies, 7, 447-509.

Carens, J. (2000). Culture, Citizenship and Community. A Contextual Exploration of Justice as Evenhandedness. Oxford: Oxford University Press.

Çınar, D. (2010). EUDO Citizenship Observatory Country Report: Austria. EUI Working Paper, RSCAS, Vol. 2010/10. Florence, Italy: Robert Schuman Centre For Advanced Studies, EUI. 
Citrin, J., Reingold, B., \& Green, D. P. (1990). American Identity and the Politics of Ethnic Change. The Journal of Politics, 52, 1124-1154.

Cohen, J. (1989). Democratic Equality. Ethics, 99, 727-751.

De Hart, B. (2010). Children's Citizenship, Motherhood and the Nation State. In M. Schrover and E. J. Yeo (Eds.), Gender, Migration and the Public Sphere, 1850-2005 (pp. 97-117). New York, NY: Routledge.

DeVoretz, D. J. (2008). The Economics of Citizenship: A Common Intellectual Ground for Social Scientists? Journal of Ethnic and Migration Studies, 34, 679-693.

Goodman, S. W. (2012). Fortifying Citizenship: Policy Strategies for Civic Integration in Western Europe. World Politics, 64, 659-698.

Gürses, H., Mattl-Wurm, S., \& Kogoj, C. (2004). Gastarbajteri: 4o Jahre Arbeitsmigration [Guest Workers: 40 Years of Labour Migration]. Vienna: Mandelbaum Verlag.

Howard, M. M. (2009). The Politics of Citizenship in Europe. New York, NY: Cambridge University Press.

Janoski, T. (2010). The Ironies of Citizenship: Naturalization and Integration in Industrialized Countries. New York, NY: Cambridge University Press.

Jones-Correa, M. (1998). Between Two Nations: The Political Predicament of Latinos in New York City. Ithaca, NY: Cornell University Press.

Jones-Correa, M. (2001). Institutional and Contextual Factors in Immigrant Naturalization and Voting. Citizenship Studies, 5, 41-56.

Kahenec, M. \& Tosun, M. S. (2009). Political Economy of Immigration in Germany: Attitudes and Citizenship Aspirations. International Migration Review, 43, 263-291.

Knop, K. (2001). Relational Nationality: On Gender and Nationality in International Law. In T. A. Aleinikoff \& D. Klusmeyer (Eds.), Citizenship Today: Global Perspectives and Practices (pp. 89-124). Washington, DC: Carnegie Endowment for International Peace.

Levesley, T. (2008). British citizenship: experience and perceptions. London, UK: EdComs Ltd.

Levitt, P. (2001). The Transnational Villagers. Berkeley, CA: University of California Press.

Levitt, P and Jaworsky, B. N. (2007). Transnational Migration Studies: Past Developments and Future Trends. Annual Review of Sociology, 33, 129-156.

Liang, Z. (1994). Social Contact, Social Capital, and the Naturalization Process: Evidence from Six Immigrant Groups. Social Science Research, 23, 407-37.

Mazzolari, F. (2009). Dual Citizenship Rights: Do They Make More and Richer Citizens? Demography, 46, 169-191.

Mussger, H., Fessler, P., \& Szymanski, W. (2001). Österreichisches Staatsbürgerschaftsrecht [Austrian Citizenship Law]. Vienna: Juridica Verlag.

OECD (2013). International Migration Outlook 2013. Paris: OECD.

Perchinig, B. (2010). All You Need to Know to Become an Austrian: Naturalization Policy and Citizenship Testing in Austria. In E. Ersbøll, D. Kostakopoulou \& R. van Oers (Eds.), A Re-definition of Belonging? Language and Integration Tests in Europe (pp. 25-50). Leiden: Brill Publishers.

Portes, A., \& Curtis, J. W. (1987). Changing Flags: Naturalization and its Determinants. International Migration Review, 21, 838-861.

Qian, Z., \& Lichter, D. T. (2007). Social Boundaries and Marital Assimilation: Interpreting Trends in Racial and Ethnic Intermarriage. American Sociological Review, 72, 68-94.

Ramakrishnan, S. K. \& Espenshade, J. T. (2001). Immigrant Incorporation and Political Participation in the United States. International Migration Review, 35, 870-909.

Rousseau, J.-J. (1997 [1762]). The Social Contract and other later political writings. Edited and translated by V. Gourevitch. Cambridge: Cambridge University Press. 
Scott, K. (2008). The Economics of Citizenship: Is there a Naturalization Effect? In P. Bevelander \& D.J. DeVoretz (Eds.), The Economics of Citizenship (pp. 105-126). Malmö: Malmö University Press.

Shachar, A. (2009). The Birthright Lottery: Citizenship and Global Inequality. Cambridge, MA: Harvard University Press.

Smith, R. (1997). Civic Ideals: Conflicting Visions of Citizenship in US History. New Haven, CT: Yale University Press.

Sniderman, P., L. Hagendoorn and M. Prior. (2004). Predisposing Factors and Situational Triggers: Exclusionary Reactions to Immigrant Minorities. American Political Science Review, 98, 35-49.

Stadler, B. and Wiedenhofer-Galik, B. (2008). Arbeits- und Lebenssituation von Migrantinnen und Migranten in Österreich:Modul der Arbeitskräfteerhebung 2008. Vienna: Statistik Austria.

Taylor, P., Lopez, M. H., Passel, J. S., \& Motel, S. (2011). Unauthorized Immigrants: Length of Residency, Patterns of Parenthood. Washington, DC: Pew Hispanic Center.

Topçu, C. (2007). Einbürgerung:Lesebuch überdas Deutsch-Werden. Frankfurt am Main: Brandes und Apsel Verlag.

Vertovec, S. (2004). Migrant Trasnationalism and Modes of Transformation. International Migration Review, 38, 970-1001.

Vink, M., Prokic-Breuer, T., \& Dronkers, J. (2012). Why immigrants naturalize in Europe: Push-pull factors and institutional conditions. Paper presented at the annual meeting of the Council for European Studies, Boston, March 22-24.

Waldrauch, H. (2006). Acquisition of Nationality. In R. Bauböck, E. Ersbøll, K. Groenendijk \& H. Waldrauch (Eds.), Acquisition and Loss of Nationality: Policies and Trends in 15 European Countries (pp. 121-219). Amsterdam: Amsterdam University Press.

Yang, P. Q. (1994). Explaining Immigrant Naturalization. International Migration Review, 28, 449-477.

\section{About the author}

Alex Street, Max Planck Institute for the Study of Religious and Ethnic Diversity. E-mail: street.alex@gmail.com.

\section{(c) (1) $(9)$}

This is an Open Access article distributed under the terms of the Creative Commons Attribution License (http:// creativecommons.org/licenses/by/2.0), which permits unrestricted use, distribution, and reproduction in any medium, provided the original work is properly cited. 